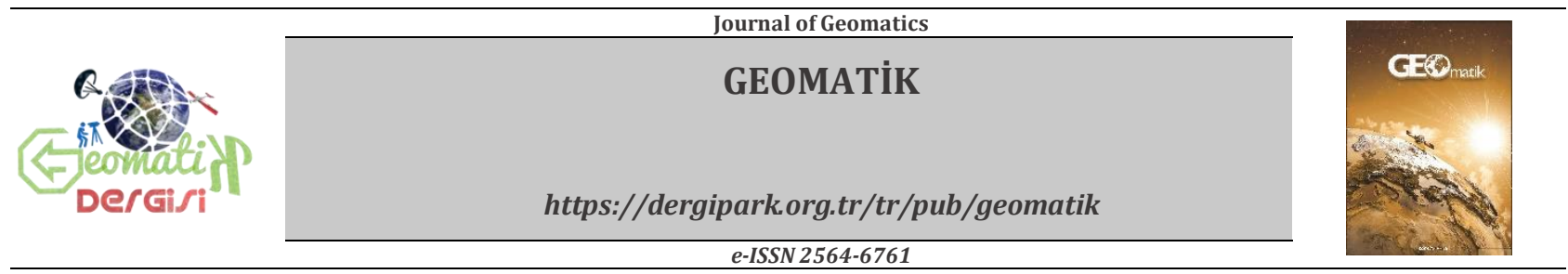

\title{
CBS ve AHP Yöntemi Yardımıyla Niğde Kenti Örneğinde Taşınmaz Değerleme
}

\author{
Aslı BOZDAĞ $\breve{G}^{* 1}$, Ela ERTUNÇ² \\ 1 Ömer Halis Demir Üniversitesi, Mühendislik Fakültesi, Harita Mühendisliği Bölümü, Niğde, Türkiye \\ ${ }^{2}$ Konya Teknik Üniversitesi, Mühendislik Fakültesi, Harita Mühendisliği Bölümü, Konya, Türkiye
}

\section{Anahtar Kelimeler \\ Çok Ölçütlü Karar Verme (ÇKKV)}

Analitik Hiyerarşi Proses

Taşınmaz Değerlemesi

ÖZ

Taşınmaz değerlemesi tarafsız ve objektif bir şekilde, taşınmazın nitelik, çevre ve kullanım koșulları gibi etmenlerin değerlendirilmesi yoluyla söz konusu tașınmaza ait değerinin belirlenmesidir. Güvenilir bir taşınmazın değer tahmini arazi özelliklerinin tarafsız bir şekilde birlikte analizi ile mümkündür. Günümüzde halen taşınmaz değerlemesi ideal sistem olarak kurulamamıștır. Bundan dolayı da tașınmaz değerlerinde tutarsızlıklar meydana gelmekte ve taşınmaza değer biçebilmek için kullanılan kriterlerin etkili bir şekilde araştırılması gerekmektedir. Bu çalışmada taşınmaz mal olan yapıların değerlemesi için literatür araştırması sonrasında 5 ana kriter ve bu kriterlerle ilişkili 38 alt kriter belirlenmiștir. Niğde kentinin gelişme bölgesinde seçilen 30 dairenin taşınmaz değeri bu kriterlere göre yapı ve yapının konumsal özellikleri açısından değerlendirilmiş ve piyasa değerleriyle karşılaștırılmıștır. Yapıların değerlemesinde bu kriterlerin önem sıralamasını belirlemek için Çok Ölçütlü Karar Verme (ÇKKV) yöntemlerinden en yaygın kullanımı olan Analitik Hiyerarși Prosesi (AHP) kullanılmıștır. Kriterlerin karşılaștırılması uzman görüşlerine göre yapılmış ve bu kriterlerin önem dereceleri ve istatistiksel olarak anlam düzeyleri hesaplanmıştır. Yapıların konumsal özelliklerin belirlenmesinde CBS yardımıyla yapılan analizlerden yararlanılmıştır. Sonuçta, seçilen 30 dairenin AHP ve CBS yöntemi kullanılarak yapılan puanlama yardımıyla tașınmaz değeri belirlenmiș ve bulunan bu değerler tașınmazların piyasa değerleri ile karşılaştırılmıștır. AHP ve CBS yardımıyla belirlenen taşınmaz değerlerinin piyasa değerleri ile uyumlu olduğu tespit edilmiștir.

\section{Real Property Valuation in the Sample of the City of Niğde through GIS and AHP Method}

\author{
Keywords \\ Multi Criteria Decision \\ Making \\ Analytic Hierarchy \\ Process \\ Immovable Valuation
}

\begin{abstract}
The real estate valuation is to determine the value of the real property impartially and objectively by evaluating the factors such as the quality, environment and conditions of use of the real property. The estimation of the value of a reliable real estate is possible by an objective co-analysis of the land properties. Today, the valuation of real estate has not been established as an ideal system. Therefore, inconsistencies occur in real estate values and the criteria used to evaluate the real estate need to be investigated effectively. In this study, 5 main criteria and 38 sub-criteria related to these criteria were determined after the literature search for the valuation of immovable properties. The immovable value of the 30 apartments selected in the development region of Niğde city were evaluated according to these criteria in terms of the structure and positional characteristics of the structure and compared with the market values. Analytical Hierarchy Process (AHP), which is the most widely used Multi-Criteria Decision Making (MCDM) methods, was used to determine the importance ranking of these criteria in the valuation of structures. The comparison of the criteria was made according to expert opinions and their significance levels and statistical significance levels were calculated. In order to determine the positional properties of the structures, the analysis carried out with the help of GIS were used. As a result, the real estate value of the selected 30 apartments was determined using AHP and GIS method and these values were compared with the market values of the properties. The values of the immovable determined with the help of AHP and GIS were found to be consistent with the market values.
\end{abstract}




\section{GíRIŞ}

Taşınmaz (taşınmaz mal=gayrimenkul); toplum yararı için geliştirilmiş sınırlamalar dışında, sahiplerine tasarruf yetkisi veren, Türk Medeni Kanunu (TMK)'na göre; arazi, tapu kütüğünde ayrı sayfada kaydedilen bağımsız ve sürekli haklar ile kat mülkiyeti kütüğüne kayıtlı bağımsız kısımlardır (Yağmahan, 2019). Taşınmazlar, gerçek ve tüzel kişiler için mülkiyetin temel parçasıdır ve bu kişilere yatırım ve kullanım aracı olarak güvence, gelir ve belirli düzeyde refah sağlamaktadır. Taşınmaz değerlemesi; taşınmazın kalite, fayda, çevre kullanım koşulları gibi faktörlere dikkat edilerek, alım-satım gününde, değerinin yansız bir şekilde tespit edilmesi işlemidir (Güngör, 1999). Günümüzde, taşınmazın değerinin belirlenmesinin önemi gün geçtikçe artmaktadır. Çünkü taşınmaz değerlemesi kamulaştırma, vergi düzenlemeleri, devletleştirme ve arazi ve toprak düzenlemeleri gibi kamusal ihtiyaçlarla, emlak ve sermaye piyasası, sigortacılık ve bankacılı gibi özel sektör ihtiyaçları için kullanılan, kamu ve kişilerin haklarının korunması yönünden de önemli bir uzmanlık dalı olmuştur.

Gelișen ve gelișmekte olan ülke ekonomilerinde taşınmazların değerinin belirlenmesi son yıllarda büyük önem kazanmıştır. Taşınmaz değerlemesi, hem taşınmazın hem de taşınmaza ilişkin hakların değerleme zamanındaki, toplumun görüşleri doğrultusunda belirledikleri değerlerinin, değerleme yöntemlerinden en az bir tanesinin kullanılmasıyla tarafsız olarak belirlenmesidir. (Çağatay ve Tecim, 2009). Taşınmazın değerini tahmin etmek için değerinin oluşumunda etkili tüm faktörlerin göz önünde bulundurulması gerekir. Farklı özelliklerdeki taşınmazların değerine etki eden faktörler ve bunların etki değerleri değişebilir. Taşınmaz değerine etki eden temel faktörler; taşınmazın kullanım amacı, mahalli özellikleri, mevzi özellikleri, konumu ve yasal durumu olarak sıralanabilir (Yağmahan, 2019). Taşınmaz değerlemesinde piyasa yöntemi, maliyet yaklaşımı ve gelir yaklaşımı gibi klasik yöntemler kullanılmaktadır (Tarin, 2013). Ayrıca son yıllarda kullanılan çok kriterli karar analizi teknikleri taşınmaz değerlemesi sürecine objektif ve doğru karar verme açısından yeni bir boyut kazandırmıștır.

Ülkemizde rekabet koşullarına dikkat edilmediğinden birçok mal ve hizmetlerin değeri yalnızca bir değer ile belirlenir. Fakat kazançlı bir yatırım aracı olarak görülen taşınmazlar için böyle tek bir değer olmamakla birlikte, değerlerdeki değişme oranlarını da kestirmek olabildiğince zordur. Özellikle ülkemizde bir taşınmazın (rayiç değeri veya alım satım değeri, vergiye esas değeri, kamulaştırma değeri, adli yargıda bilirkişiler tarafından tespit edilen mahkeme değeri gibi) değişik değerleri olabilmektedir. Hâlbuki bir taşınmazın belirli bir zaman diliminde tek bir değerinin olması gerekmektedir. Değişik yöntemler ile taşınmaz değeri tespit edilse bile bu değerlerin kabul edilebilir, birbirine yaklaşan değerler olmalıdır. Bilimsel çalışmalar bu farkın \% 15-20’ yi geçmemesi gerektiği yönündedir (Açlar ve Çağdaş, 2002). Ülkemizde taşınmaz değerlemesi için net bir standarttın oluştuğu söylenememektedir. Bundan dolayı da değişik fiyatlar söz konusu olabilmektedir. Bunun sonucunda nesnel bir değerleme yapılamamaktadır.

Karar verme insanoğlunun hayatının her döneminde farklı konular üzerinde karşısına çlkmaktadır. Karar verme, bir düşüncenin veya davranışın olası diğer seçenekler içinden seçilmesiyle sonuçlanan zihinsel bir işlemdir. Kuşkusuz, karar verme süreci, hedeflenen sonuçların bireyle, grupla, düzenlemeyle veya kararın belirli bir konuyla ilgili durumuna göre değişebilmektedir. Genellikle rutin kararlar vermek zorunda kalan bireyler, bu süreçte çoğunlukla, sezgisel yaklaşımları kabullenirken; bir işletme veya grupla ilgili durumlarda bilimsel temellere dayalı yaklaşımlar kabullenmektedir (Uludağ ve Doğan, 2016). Belirlenen kriterlerin ikili karşılaştırmalarına dayanan (ÇKKV) yöntemleri nümerik verilerle en doğru kararın verilmesine yardımcı olmaktadır. ÇKKV yöntemlerinin kendi içerisinde birbirlerine göre birtakım üstünlükleri vardır. Bu yüzden bir problemin çözümünden önce kullanılacak yöntemin hangisinin daha elverişli olduğu belirlenmelidir. Karar verici, problemin yapısı ve sürecin özelliklerine bakarak en elverişli yöntemi belirler (Ersöz ve Kabak,2010). AHP yöntemi, çok kriterli karar verme yönteminin nicel ve nitel çözümlemesinin birleşimidir. Bu yöntem, karar verme sorununu nitel yönden kritere, alternatiflere ayırarak ve bu etkenlerin bütünsel yapısı içindeki ilișkiyle niceleyici hiyerarşi önem ağırlıkları hesaplar, çeşitli etkenlerin göreli önemini inceler ve kararını ifade eder. AHP, kompleks problemlerin kolayca ve çözülebilir hale gelmesi için yalın bir hiyerarşi ve analitik proseslere sahiptir. Neredeyse her karar verme sürecinde kullanılabilen bu yöntemin geniș bir uygulama alanı vardır (Hamurcu ve Eren, 2017). Bir karar verme problemi olan taşınmaz değerleme için çok kriterli karar verme yöntemi kullanılabilir (Demirel ve ark., 2018).

CBS, yeryüzündeki karmaşık çevresel, sosyal, kültürel ekonomik sorunları çözebilmek adına mekânsal ve konuma dair karar verme süreçlerinde kullanıcılara yardımcı olabilmek, önemli miktarda coğrafi verilerin; işlenmesi, biriktirilmesi, bir araya getirilmesi, idare edilmesi, mekânsal analizi, sorgulanması ve sunulması fonksiyonlarını yerine getiren yazılım, donanım, personel, coğrafi veri ve yöntemler bütünüdür (Yağmahan, 2019). CBS'nin farklı disiplinlerde ki problemlere çözüm getiren bir araç olması taşınmaz değerlemesi alanında da kullanımını yaygınlaștırmaktadır.

Bahar (2007) çalıșmasında, taşınmaz değerlemesinde Coğrafi Bilgi Sistemleri (CBS) 'nin kullanım olanaklarını incelemiştir. Torun ve ark. (2009), taşınmaz değerlemesinde ekonomik olarak istenilen noktaya gelinememesi kaynaklı sorunun çözümüne yönelik Coğrafi Bilgi Sistemleri 
yardımıyla taşınmaz değer haritalarının üretimini araştırmışlardır. Araştırmacılar bu çalıșmada, Çoklu Karar Verme Analizi ve CBS kullanmıșlardır. Döner (2010) çalışmasında taşınmazların değer haritalarının mobil tabanlı CBS uygulaması ile oluşturulmasına yönelik uygulama yapmıștır. Özer (2010), TOPSIS ve (ÇKKV) yöntemlerini kullanarak belirlenen taşınmaz ölçütlerinin piyasa ve gerçek değer karşılaştırmasını yapmıştır. Yılmaz ve Demir (2011) yaptıkları çalışmada, (ÇKKV), CBS ve oran çalışması ile değerleme işlemlerini nesneleştiren ve sonuçları kontrol edilebilir bir model geliştirilmeyi amaçlamıştır. Yalpır ve Ekiz (2017) yaptıkları çalışmada, taşınmaz değerlemesinde eşdeğerlilik esaslı arsa ve arazi düzenlemesinde Analitik Hiyerarşi Prosesinin kullanım olanaklarını araştırmışlardır. Döner ve Alkan (2011), taşınmaz değerlemede karşılaşılan problemlerin çözümü için CBS destekli taşınmazların değer haritalarını oluşturmuşlardır. Derinpınar ve Aydınoğlu (2015), Bulanık Mantık, CBS ve Nominal değerleme yöntemleri ile taşınmaz değerlemesi yapmışlardır. Çağatay (2012), kentlerde etkili bir konut ve arsa politikası oluşturulmasına yönelik, CBS kullanılarak taşınmaz değer haritalarını oluşturmuştur. Amca (2016) yaptığı çalıșmada, tașınmazın gerçek değerinin belirlemesi için regresyon modeli ile hangi unsurların taşınmaz fiyatını azalttığı veya artırdığını tespit etmiştir ve regresyon modelini kullanılarak gerçek değer analizi yapmıştır. Ünel ve Yalpır (2014), taşınmaz değerlemesinde AHP ve CBS metotları ile parsellerin konumsal, fiziksel ve yasal durumlarını belirlemişlerdir. Erbil (2014), taşınmaz mal değerlemesinde mevzuat ve idari yapılanma sorunlarını çözüme kavuşturma amaçlı CBS kullanarak bir yöntem önermiştir. Erdem (2017a), hukuksal, teknik ve kurumsal bileşenleri barındıran taşınmaz değerleme sistemi (TADES) önermiştir. Ünel ve ark. (2017), taşınmaz değerini etkileyen kriterlerin yaş gruplarına bağlı olarak değişimini incelemişlerdir. Ertaş ve Bayındır (2017), entegre kapitülasyon oranı yöntemini taşınmaz değerlemesinde kullanmışlarıdır. Erdem (2017b), Türkiye'deki taşınmaz değerleme sisteminin mevcut durumunu araştırarak sistemin daha sağlıklı olması için bir yaklaşım önermiştir. Demirel ve ark. (2018), taşınmaz değerlemesini etkileyen kriterler ve bu kriterlerin önem basamaklarını (ÇKKV) ile araştırmışlardır. Timur (2019), İstanbul ili Şişli ilçesi örneğini seçerek CBS destekli taşınmaz değer haritalarını oluşturmuştur. Timur bu çalışmasında CBS raster tekniği ile taşınmaz değer haritaları üretmiştir. Ünel ve Yalpır (2019), yaptıkları çalışmada Türkiye'de taşınmazların değerini etkileyen kriterleri kapsaml bir şekilde araştırmışlardır. Erdem (2019) çalışmasında Türkiye'de taşınmaz değerleme alanında yapılan faaliyetlerle ilgili mevcut durumu incelemiş ve bu alandaki sorunları belirlemiştir. Ertaş (2019) Türkiye'de gayrimenkul değerleme eğitimi üzerine çalışma yapmıştır.
$\mathrm{Bu}$ çalışmada (ÇKKV) yöntemi kullanılarak Niğde ilinde mevcut duruma göre taşınmaz değerine etki eden kriterler incelenmiștir. Kriterlerin belirlenmesinde Niğde Belediyesi, Niğde Ömer Halis Demir Üniversitesi Harita Mühendisliği, İnşaat Mühendisliği, Çevre Mühendisliği ve Mimarlık ve Şehir Planlama Bölümü öğretim üyeleri ve gayrimenkul değerleme uzmanları ile yapılan anket sonucu konum, ulaşım, altyapı, nüfus ve yapı (bina) özellikleri olmak üzere 5 adet ana kriter ve bu kriterlere bağlı olarak 38 adet alt kriter belirlenmiștir. Kriterlerin önem düzeyi birbiriyle olan korelasyonu istatistiksel olarak \%95 güven düzeyinde incelenmiştir. Kriterlerin önem düzeyleri belirlenmesinde AHP yöntemi kullanılmıştır. AHP ile hesaplanan katsayılar şeklinde olan ağırlıklar CBS ile entegre ederek çalışma alanında konumsal analizler yapılmıştır. Niğde ilinde bulunan 30 taşınmazın değeri AHP ve CBS yöntemleriyle yapısal ve konumsal olarak belirlenmiş ve bu taşınmazların değeri mevcut piyasa değeri ile karşılaştırılmıştır.

\section{YÖNTEM}

\subsection{Analitik Hiyerarşi Süreci}

AHP, karar vericinin mevcut tüm alternatifleri, bunlara ait tüm kriterlere göre değerlendirerek, göreli kriterlerin önem durumlarına ikili karşılaştırmalar yapması esasına göre çalışmaktadır. AHP 'nin hiyerarşik yapısına göre, karar vericinin hedefi en üst seviyede bulunmaktadır. Hiyerarşik yapıda alt seviyelere doğru inildikçe kriterler ve bu kriterlere ait alt-kriterler mevcuttur. Hiyerarşi seviyesi düştükçe alt kriterlere erişilmekte ve bu kriterlerin ayrıntılarına inilmekte, başka bir deyişle belirginleşmektedir.

AHP uygulamasında öncelikle kriterlerin ikili karşılaştırma matrisleri oluşturulmalıdır. İkili karşılaştırma matrisi, AHP 'nin asıl verilerini olușturmaktadır. Matris, bütün alternatiflerin, tüm alt-kriterler altında mukayese edilmesine dayanmaktadır. Her bir seviyedeki kriterler, bir sonraki üst seviye kriterine göre önemi bakımından ikili bir şekilde karşılaştırılır. Hiyerarşinin tepesinden aşağıya doğru işlem devam ederken, belirli bir seviyedeki ikili karşılaştırmalar aşağıdaki gibi çoklu kare matrislere $\quad\left(K=\left[K_{i j}\right]_{n x n}\right)$ indirgenebilir:

$$
\left[\begin{array}{lll}
K_{11} & K_{12} & K_{13} \\
K_{21} & K_{22} & K_{23} \\
K_{31} & K_{32} & K_{33}
\end{array}\right]
$$

Karşıt özelliklere sahip matris $\mathrm{R}=\left[\frac{1}{K_{i j}}\right]_{n x n}$ aşağıdaki gibidir:

$$
\left[\begin{array}{ccc}
\frac{1}{K_{11}} & \frac{1}{K_{12}} & \frac{1}{K_{13}} \\
\frac{1}{K_{21}} & \frac{1}{K_{22}} & \frac{1}{K_{23}} \\
\frac{1}{K_{31}} & \frac{1}{K_{32}} & \frac{1}{K_{33}}
\end{array}\right]
$$


HP 'de, Saaty (1980) 'de önerildiği gibi, öznel ikili karşılaştırmalar yapmak için önem derecesine göre 1 'den 9 'a kadar numaralandırılmış bir ölçek kullanılır (Tablo 1). Illk olarak, tüm ikili karşılaştırma matrisleri olușturulur. Sonra, Saaty'nin özvektör prosedürü temelinde ağırlık vektörü $W=$ $\left[W_{1}, W_{2}, \ldots, W_{n}\right]$ hesaplanır.

Ağırlıkların hesaplanması iki adımda gerçekleștirilir: (1) normalize edilmiş ikili karşlaş̧tırma matrisi oluşturulur ve (2) ağırlıklandırılmış matris oluşturulur. Tablo 1 'de oransal önem ölçeği, ikili karşılaştırma için Saaty tarafından geliştirilen 1-9 ölçeğine göre tanımlanmıştır.

Olușturulan ikili karşılaștırma matrisi $K=$ $\left[K_{i j}\right]_{n x n}$ dir. Normalize edilmiş bir ikili karşılaştırma matrisi elde etmek için matris içindeki her bir elemanın sütun toplamına bölündüğü (1) eşitliği kullanılarak normalize edilir (Chen, 2006; Bunruamkaew, 2012)

$$
N_{i j}=\frac{K_{i j}}{\sum_{i=1}^{n} K_{i j}}\left[\begin{array}{lll}
N_{11} & N_{12} & N_{13} \\
N_{21} & N_{22} & N_{23} \\
N_{31} & N_{32} & N_{33}
\end{array}\right]
$$

Bütün j değerleri için de (1) eşitliği uygulanır.

Tablo 1. 9 Puanlık Göreli Önem Ölçeği ve Açıklamaları (Saaty, 1980)

\begin{tabular}{|c|c|c|}
\hline Önem Ölçeği & Tanım & Açıklama \\
\hline 1 & Eşit derecede önemli & İki seçenek eşit derecede öneme sahiptir \\
\hline 3 & Orta derecede önemli & Tecrübe ve yargı bir kriteri diğerine karşı biraz üstün kılmaktadır \\
\hline 5 & Kuvvetli derecede önemli & $\begin{array}{l}\text { Tecrübe ve yargı bir kriteri diğerine karşı oldukça üstün } \\
\text { kılmaktadır }\end{array}$ \\
\hline 7 & $\begin{array}{l}\text { Çok kuvvetli derecede } \\
\text { önemli }\end{array}$ & Bir kriter diğerine göre üstün sayılmıștır \\
\hline 9 & Kesin önemli & $\begin{array}{l}\text { Bir kriterin diğerinden üstün olduğunu gösteren kanıt çok büyük } \\
\text { güvenirliğe sahiptir }\end{array}$ \\
\hline $2,4,6,8$ & Ara değerler & $\begin{array}{l}\text { Uzlașma gerektiğinde kullanılmak üzere iki ardışık yargı } \\
\text { arasındaki değerlerdir }\end{array}$ \\
\hline $\begin{array}{l}\text { Yukarıdaki sıfır } \\
\text { olmayan sayıların } \\
\text { karșıtları }\end{array}$ & $\begin{array}{l}\text { Ters karşılaştırma için } \\
\text { karşıtlar }\end{array}$ & \\
\hline
\end{tabular}

Ağırlıklar, matrisin normalize edilmiş sütunları toplamının ağırlıklandırılmış matrisi elde etmek için kullanılan kriter sayısına (n) bölündüğü (2) eşitliği kullanılarak hesaplanır (Bunruamkaew 2012).

$$
W_{i j}=\frac{\sum_{j=1}^{n} N_{i j}}{n}\left[\begin{array}{l}
W_{11} \\
W_{12} \\
W_{13}
\end{array}\right]
$$

Bütün $i$ değerleri için de (2) eşitliği uygulanır. Tutarlılık vektörünü elde etmek için, ikili karşılaştırma matrisi ağırlık vektörü ile çarpılır; yani,

$\left[\begin{array}{lll}K_{11} & K_{12} & K_{13} \\ K_{21} & K_{22} & K_{23} \\ K_{31} & K_{32} & K_{33}\end{array}\right] x\left[\begin{array}{l}W_{11} \\ W_{12} \\ W_{13}\end{array}\right]=\left[\begin{array}{l}K_{11} \\ K_{12} \\ K_{13}\end{array}\right]$

Ardından, ağırlıklı toplam vektörü kriter ağırlı̆̆ına bölünerek elde edilir;

$$
\begin{aligned}
& K_{v_{11}}=\frac{1}{w_{11}}\left[K_{11} W_{11}+K_{12} W_{21}+K_{13} W_{31}\right] \\
& K_{v_{21}}=\frac{1}{w_{21}}\left[K_{21} W_{11}+K_{22} W_{21}+K_{23} W_{31}\right](4) \\
& K_{v_{31}}=\frac{1}{w_{31}}\left[K_{31} W_{11}+K_{32} W_{21}+K_{33} W_{31}\right]
\end{aligned}
$$

Ağırlık vektörü $\mathrm{W}$ ile ikili karşılaştırma matrisi $\mathrm{K}$ arasında aşağıdaki gibi bir iliş̧i vardır (Chen, 2006);

$K_{W}=\lambda_{\max } W$

Karșılaștırma matrisinin maksimum öz değeri olan $\lambda \_$max değeri (Mikhailov ve Tsvetinov 2004)
AHP 'de önemli bir doğrulama parametresidir. Hesaplanan vektörün tutarlılık oranını (CR) hesaplayarak bilgileri yansıtmak için referans indeksi olarak kullanılmaktadır (Chen 2006). $\lambda$, (6) eşitliği kullanılarak formüle edilen tutarlılık vektörünün değerinin ortalaması alınarak elde edilmektedir (Bunruamkaew 2012).

$\lambda=\sum_{i=1}^{n} K_{v_{i j}}$

CR'yi hesaplamak için, n'inci dereceden her bir matris için tutarlılık indeksi (CI), eşitlik (7) ile elde edilebilir (Chen, 2006).

$C I=\frac{\lambda_{\max }-n}{n-1}$

Sonra CR, CI ve RI'nın birbirine oranı olarak eșitlik (8) ile verilebilir; $C R=\frac{C I}{R I}$

Burada RI, rastgele oluşturulmuş bir ikili karșlaștırma matrisinden elde edilen rastgele tutarlılık indeksidir. Tablo 2, 1 'den 15 'e kadar olan matrisler için RI değerlerini göstermektedir (Saaty, 1980). Herhangi bir seviyedeki herhangi bir daha yüksek değer (RI > 0.01), karar vericilerin kararlarını yeniden incelemeye gerek duyduğunu belirtir (Bunruamkaew, 2012). Bu durumda Analitik Hiyerarşi Sürecinin 3. adımdan başlayarak gözden geçirilmesi ve revize edilmesi gerekmektedir (Chen, 2006). 
Tablo 2. N=1-15 İçin Rastgelelik İndex Değerleri (Saaty, 1980)

\begin{tabular}{llllllllllllllll}
\hline \multicolumn{1}{l}{ Random Index (RI) } \\
\hline $\mathrm{N}$ & 1 & 2 & 3 & 4 & 5 & 6 & 7 & 8 & 9 & 10 & 11 & 12 & 13 & 14 & 15 \\
$\mathrm{RI}$ & 0.00 & 0.00 & 0.58 & 0.90 & 1.12 & 1.24 & 1.32 & 1.41 & 1.45 & 1.49 & 1.51 & 1.48 & 1.56 & 1.57 & 1.58 \\
\hline
\end{tabular}

Bir karar verme probleminde yer alan tüm kriterlerin ikili karş̧laştırmalarının toplam ölçütünü oluşturmak için, bireysel değerlendirmelerin (9) eşitliği kullanılarak ortalaması alınmaktadır.

$$
k_{i j}^{h p}=\sqrt[q]{\prod_{q=1}^{q} k_{i j}^{q}}
$$

Burada, $\boldsymbol{k}_{i j}^{\boldsymbol{q}}$ bir $\boldsymbol{q}(\boldsymbol{q}=\mathbf{1}, \mathbf{2}, \mathbf{3}, \ldots, \boldsymbol{Q})$ kriterinin $\mathrm{K}$ matrisinin bir elemanı ve $\boldsymbol{k}_{i j}^{h p}$ tüm $\boldsymbol{k}_{i j}^{q}$ kriterlerinin aritmetik ortalamasıdır. Grup CR eşitlik (7) ve (8) 'e göre hesaplanmaktadır (Saaty, 1980; Chen, 2006; Akalın ve ark., 2013).

\section{BULGULAR}

\subsection{Niğde İli Taşınmaz Değerine Etki Eden Kriterlerin Belirlenmesi}

Tablo 3. Niğde Kenti İçin Belirlenen Taşınmaz Değerine Etki Eden Kriterler

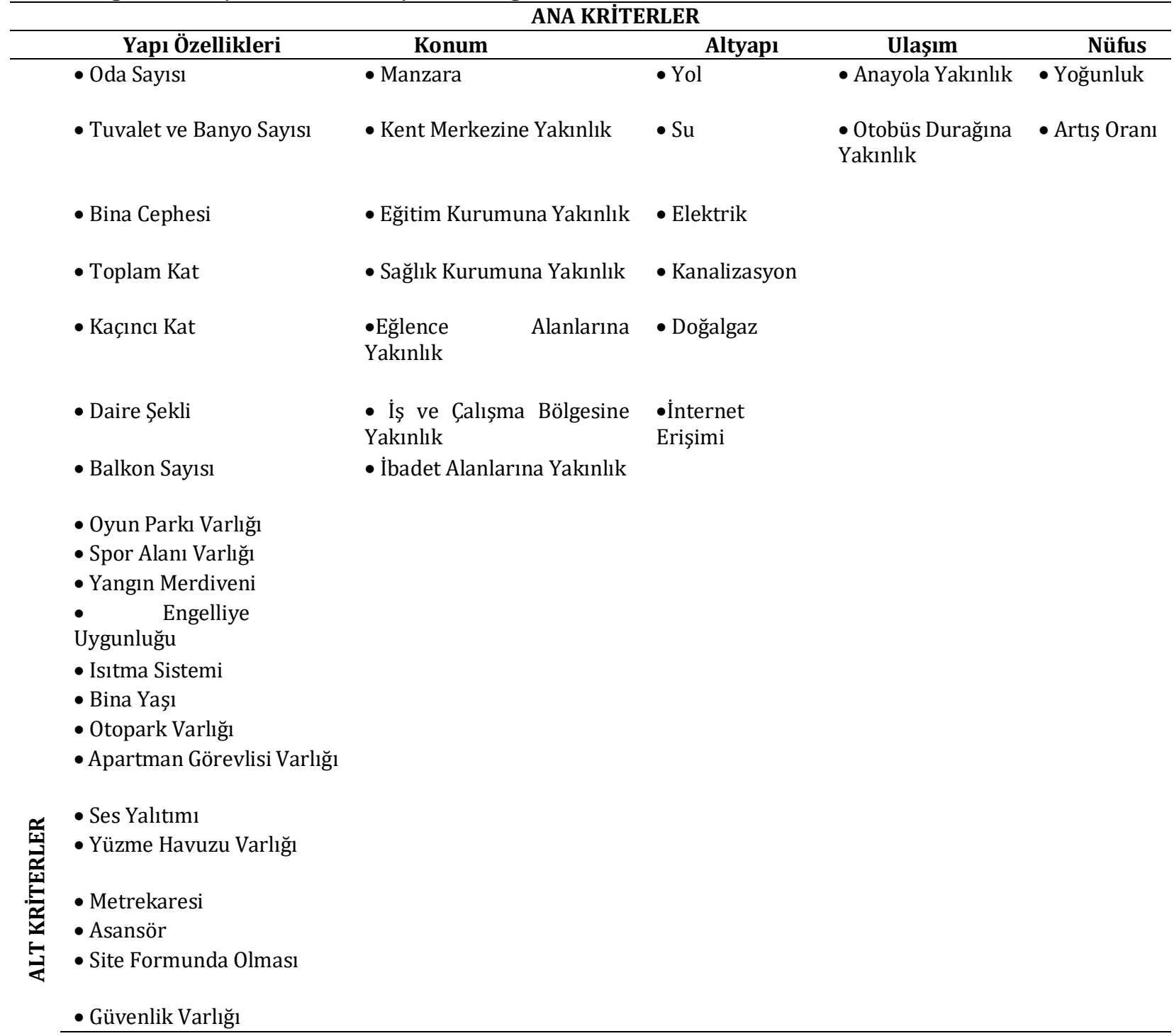

Literatür araștırması ve Niğde ilinde yapılan inceleme ve analizlere göre taşınmaz değerini etkileyen ana kriterler (Yapı özellikleri, Konum, Altyapı, Ulaşım ve Nüfus) tespit edilmiştir.

Taşınmaz değerlemede önemli olan bir diğer karar verme problemi de belirtilen ana kriterlere ait olan alt kriterlerdir. Örneğin; konuma ait olup alt kriter olarak belirtilen "iş ve çalışma bölgesine uzaklık" kișiler tarafından farklı șekillerde olabilir. Temel seçim kriteri aynı olmakla birlikte seçim yapacak olan kişiye göre kriterlerin önem derecesi farklılık gösterecektir. Bu yüzden taşınmaz değeri ana kriterlerine ek olarak literatürden yararlanarak alt kriterler seçilmiştir (Tablo 3) 
Bu kriterlerden Niğde ili için hangisinin daha çok önem taşımakta olduğu ve buna ilişkin önem düzeyinin ölçülmesi amacıyla kamu kurum kuruluşlarında ve özel sektörde bulunan 60 kiși ile anket yapılmıştır. Şekil 1'de anketin kimlerle yapıldığı ve ankete katılan kişi sayısı gösterilmektedir.

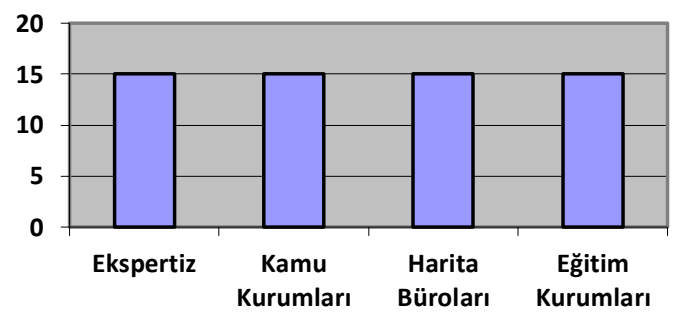

口Ankete katılan kişi sayıs

Şekil 1. Ankete Katılan Kişilerin Dağılımları

Taşımaz değerlemesinde yer alan alt kriterler taşınmaz değerine etki eden ve kişinin ihtiyacına yönelik farklı önem derecesi alabilecek kriterlerdir. Kişinin talepleri doğrultusunda bu kriterlere eklemeler yapılabilir veya burada sayılmış olan kriterler azaltılabilir. Ayrıca değerin sübjektif olması ve kriterleri fiyata olan etkisini belirlemede farklı düşünceler değerlemeyi zorlaştırmaktadır. Taşınmazların değerinin belirlenmesinde öyle kriterler belirlenmelidir ki; her biri sayısal ifadelerle tanımlanabilmeli ve matematik ve hiyerarșik modeller içerisinde ifade edilebilmelidir. Aynı zamanda da bu kriterler her yerdeki insanlar için aynı değeri ve anlamı ifade edebilmeli ve kişisel düşünce kullanılmamalıdır. Anket sonuçları SPSS 22 programı ile değerlendirilmiștir ve sonuç olarak her bir kritere ilişskin önem düzeyleri belirlenmiștir. Belirlenen kriterler arasında eşdoğrusallık sorununun önlenmesi amaciyla korelasyon analizi gerçekleştirilmiştir.

Anket uygulamasında değişkenler üzerinde anket puanlaması yapılmıştır. $\mathrm{Bu}$ nedenle değişkenler sıralı (ordinal) değisskenlerdir ve normal dağılım göstermemektedirler.
Değişkenlerin sayısı 30 olduğu için değișkenlerin Normallik testi "Shapiro-Wilk'e" göre yapılmıștır. Buna göre Sig $<0.05$ 'den küçük ve çarpıklık ve basıklık değerleri (George ve Mallery, 2010)'e göre incelendiğinde verilerin normal dağılmadığı görülmektedir.

Kriterler arası ilişkilerin tespiti için kriterlerin birbiri arasinda nonparametrik korelasyon her bir ana alt kriter (altyapı, nüfus, ulaşım, yapı özellikleri, konum) altında gerçekleştirilmiştir. İlk olarak değişkenlerin ikili karşılaştırabilmesi sağlanmıştır.

Değişkenler non-parametrik dağılım gösterdikleri için Spearmman korelasyon katsayısı seçilmiştir. Korelasyon değerlerine bakılarak eşdoğrusallığın engellenmesi amacıyla bazı kriterler azaltılmış veya tek başlık altında toplanılmıștır.

\subsection{Taşınmaz Değerine Etki Eden Kriterlerin AHP Yardımıyla Ağırlıklandırılması}

AHP yöntemine göre yer seçiminin yapılabilmesi için belirlenen kriterlere göre hiyerarşik düzen oluşturulmuştur. Daha sonra kriterler arasında ikili karşılaștırmalar yapılmıştır. Elde edilen ikili karşılaștırma matrislerinden normalizasyon matrisleri olușturulmuștur. Normalizasyon matrislerinden de öncelik vektörleri hesaplanmıştır. İkili karşılaştırmaların, kendi içerisindeki tutarlılığını kontrol etmek için tutarlılık testleri yapılmıştır. Tutarlılık oranı, karar vericilerin ikili karşılaştırmalar sonucunda elde ettikleri kararların güvenilirliğini sorgulamak için hesaplanmaktadır. Bu oranın değeri 0,1 veya daha küçük bir değer olması durumunda, çift yönlü karşılaştırmalar kabul edilebilir bir tutarlılığa sahip olduğu varsayılır. Değer 0,1'in üzerinde çıması sonucun güvenilir olmadığının ve tutarsız kararların göstergesidir. Test sonucunda tüm sonuçlar 0,1 değerinden küçük çıktığından bu çalışma için kullanılabilir olduğu görülmüştür.

Taşınmaz değerlemede kullanılan ana kriterlerin ağırlıkları Şekil 2 'deki gibi olup bu kriterlerden en önemlisi \%23 ile yapı özellikleri ve altyapıdır. Daha sonra en önemli kriter ise \%22 ile konum kriteridir. Bunu \%19 ile ulașım, \%14 ile nüfus kriterleri izlemektedir.

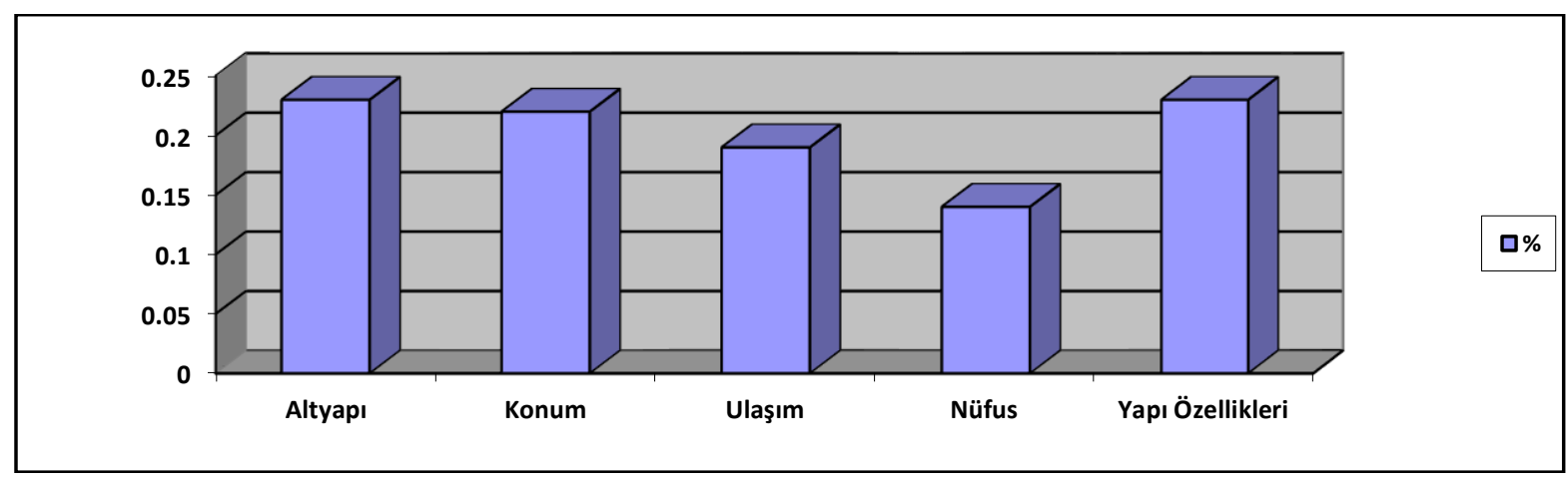

Şekil 2. AHP Çözümü Sonucunda Ana Kriterlerin Ağırlıkları 
Konum ana kriterin alt kriteri olan manzara ve iş ve çalışma merkezine yakınlık \% 23, kent merkezine yakınlık \%22 oranla en önemli kriterlerdir (Şekil 3).
Altyapı ana kriterinin alt kriterlerinden yol, su, elektrik, doğalgaz ve kanalizasyon \% 17'lik eşit önem derecesine sahiptir (Șekil 4).

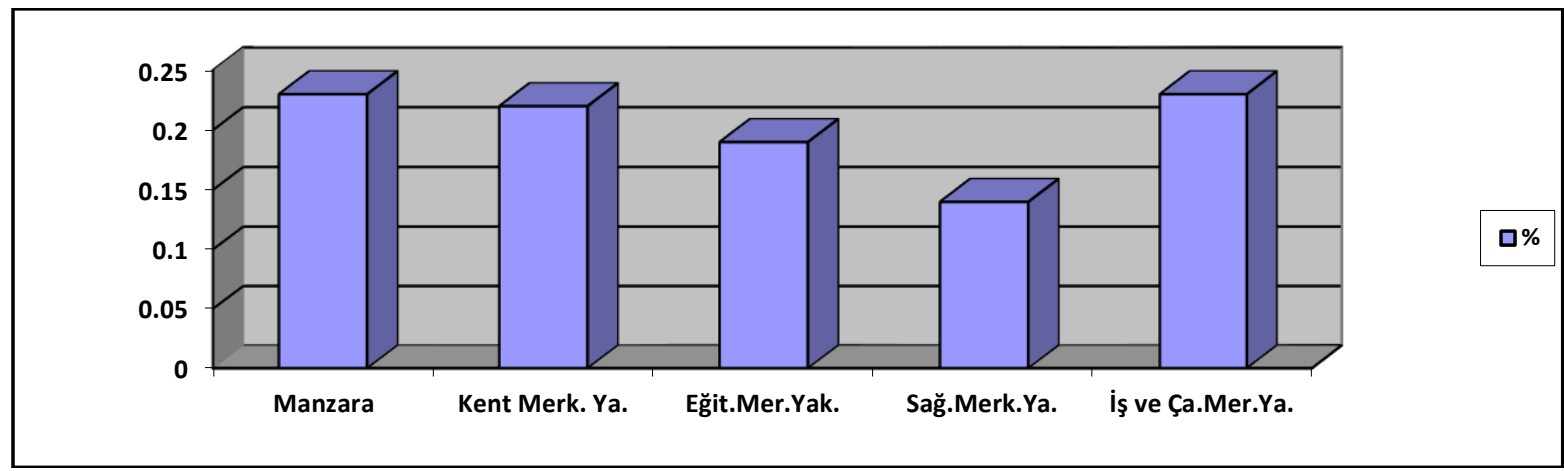

Şekil 3. AHP Çözümü Sonucunda Konum Kriterinin Alt Kriterlerinin Ağırlıkları

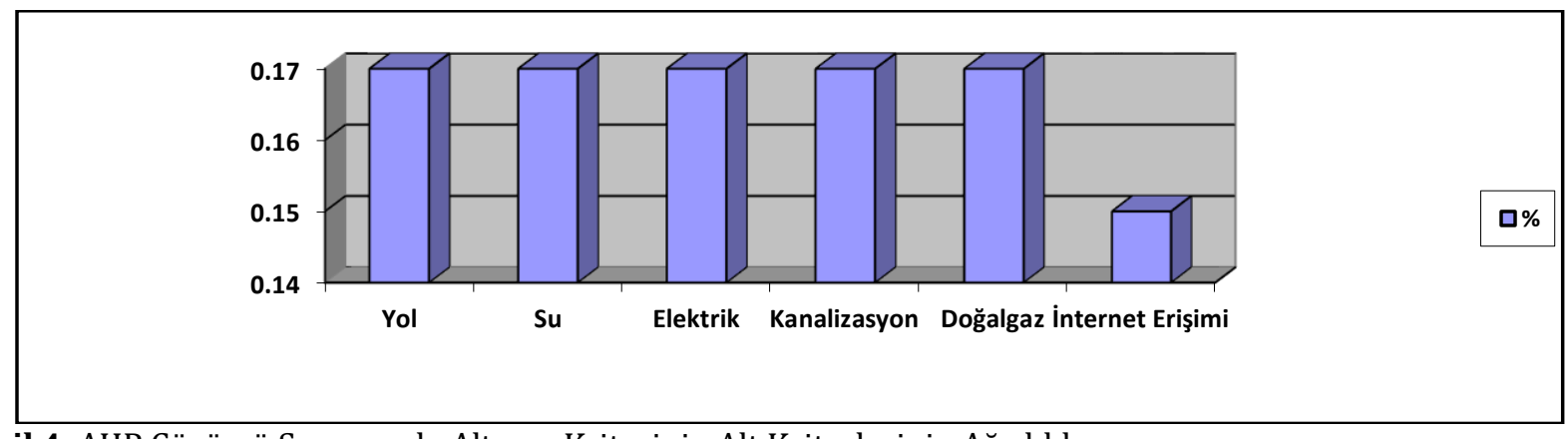

Şekil 4. AHP Çözümü Sonucunda Altyapı Kriterinin Alt Kriterlerinin Ağırlıkları

Ulaşım ana kriterinin alt kriterlerinden otobüs duraklarına yakınlık, ana yola yakın olma durumundan daha fazla önem derecesine sahiptir (Şekil 5).
Nüfusun alt kriterlerinden nüfus artış oranı ve nüfus yoğunluğuna bakıldığında ikisi de eşit önem derecesine sahiptir (Şekil 6).

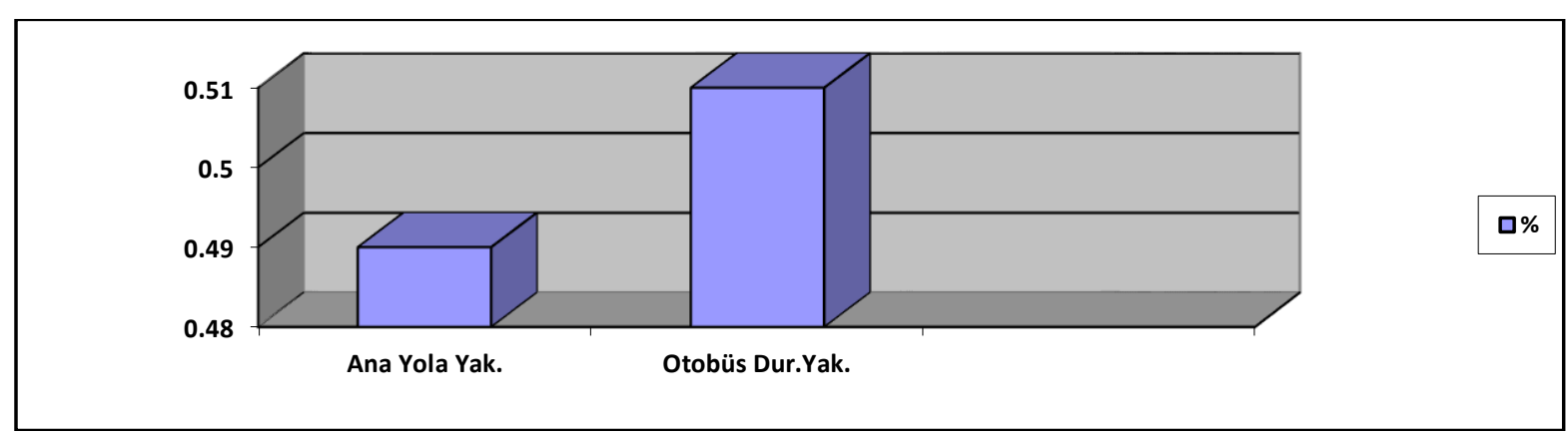

Şekil 5. AHP Çözümü Sonucunda Ulaşım Kriterinin Alt Kriterlerinin Ağırlıkları

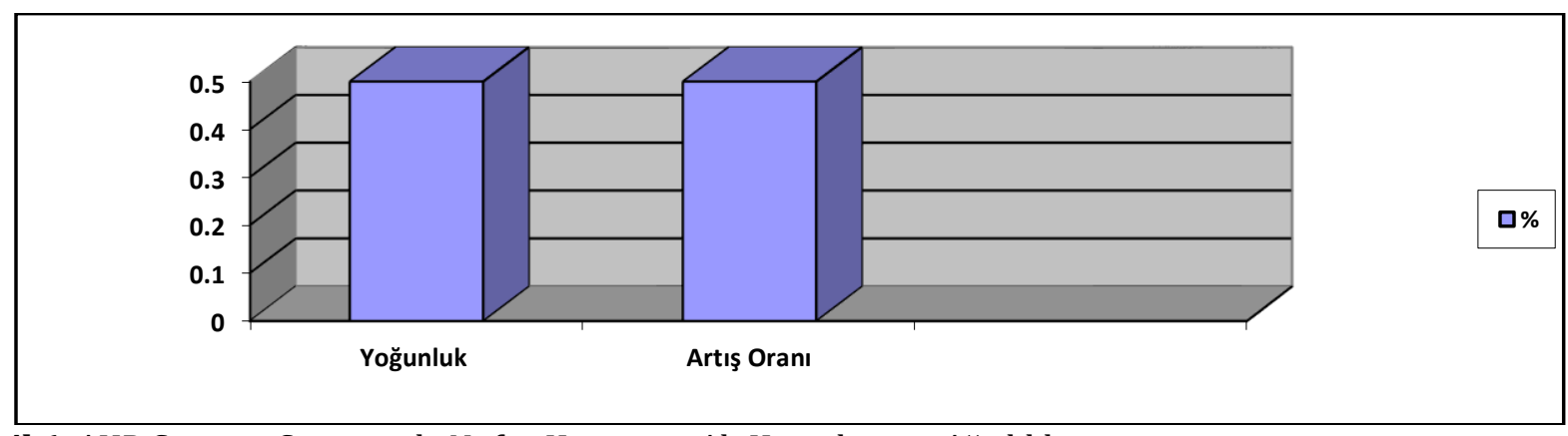

Şekil 6. AHP Çözümü Sonucunda Nüfus Kriterinin Alt Kriterlerinin Ağırlıkları 
Tablo 4' de verilen lokal ağırlıklar yapı ve konumsal özelliklerin puanlandırılmasında uzman görüșlerine dayalı bir ağırlıklı puanlandırma oluşturmak için kullanılmıştır.

Tablo 4. Ana Kriterlere İlişkin Lokal Ağırlıklar ve Tutarllıkları

\begin{tabular}{lll}
\hline Kriterler & $\begin{array}{l}\text { Lokal } \\
\text { Ağırlıklar }\end{array}$ & Tutarlılıklar \\
\hline Konum & 1.091 & 0.0158 \\
Altyapı & 1.147 & 0.0467 \\
Ulaşım & 0.939 & 0.0280 \\
Nüfus & 0.686 & 0.0701 \\
Yapı & 1.137 & 0.0562 \\
Özellikleri & & \\
\hline
\end{tabular}

\subsection{Taşınmazın Değerine Etki Eden Yapısal Özelliklerin AHP yardımıyla Puanlandırılması}

Taşınmaza etki eden ana kriterlerin alt kriterleri puanlandırılmıştır. Așağıda Tablo 5 'de yapısal özelliklerin puanlandırılmasında izlenen sistem bulunmaktadır. Buna benzer olarak altyapı, nüfus ve ulaşım ana kriterleri de puanlandırılmıştır.

Her bir ana kriterin toplam puanı lokal ağırlığı ile çarpılarak ağırlıklı toplam puan elde edilmiștir. Tablo 6 'da sadece EV 1 için yapı özellikleri yönüyle yapılan puanlama görülmektedir.
Tablo 5. Yapı Özellikleri Alt Kriterlerinin Puanlandirma Tablosu

\begin{tabular}{|c|c|c|}
\hline $\begin{array}{l}\text { Yapisal } \\
\text { Etmenler }\end{array}$ & $\begin{array}{l}\text { Puanlandirma } \\
\text { Kriteri }\end{array}$ & Puanı \\
\hline $\begin{array}{l}\text { Güvenlik } \\
\text { sistemi }\end{array}$ & Var-Yok & $10-0$ \\
\hline Spor kompleksi & Var-Yok & $10-0$ \\
\hline Kapıcı dairesi & Var-Yok & $10-0$ \\
\hline Asansör & Var-Yok & $10-0$ \\
\hline $\begin{array}{l}\text { Otopark } \\
\text { durumu }\end{array}$ & Var-Yok & $10-0$ \\
\hline Balkon & Balkon adeti & $0-1-2-3$ \\
\hline $\begin{array}{l}\text { Oyun } \\
\text { varlığl }\end{array}$ & Var-Yok & $10-0$ \\
\hline Oda sayısı & Var-Yok & $2-3-4-5-6$ \\
\hline Yüzme havuzu & Var-Yok & $10-0$ \\
\hline $\begin{array}{l}\text { Engelliye } \\
\text { uygunluğu }\end{array}$ & Var-Yok & $10-0$ \\
\hline Site & Var-Yok & $10-0$ \\
\hline $\begin{array}{l}\text { Yangin } \\
\text { merdiveni }\end{array}$ & Var-Yok & $10-0$ \\
\hline Cephe & G-GD-GB-KD-KB-K & $\begin{array}{l}10-9-8-7- \\
6-5\end{array}$ \\
\hline Isınma sistemi & $\begin{array}{l}\text { Kombi-Merkezi } \\
\text { sistem-Soba }\end{array}$ & $10-10-0$ \\
\hline Bulunduğu kat & $\begin{array}{l}\text { Üst kat-Orta kat-Alt } \\
\text { kat }\end{array}$ & $10-7.5-5$ \\
\hline Bina yașı & Yașı & $0-17$ arası \\
\hline
\end{tabular}

Tablo 6. EV 1 İçin Yapı Özellikleri Alt Kriterlerinin Ağırlıklı Puanlandırılması

\begin{tabular}{|c|c|c|c|c|c|}
\hline \multicolumn{6}{|l|}{ EV 1 (239) } \\
\hline & & $0-10$ & Toplam Puan & Lokal Ağırlık & Son Puan \\
\hline \multirow[t]{8}{*}{ Bina Ayrıntı Özellikleri } & Oda Sayısı (4+1) & 10 & 75 & 1.136975414 & 221.7102057 \\
\hline & Tuvalet ve Banyo Say. & 10 & & & \\
\hline & Bina Cephesi & 10 & & & \\
\hline & Toplam Kat Sayısı & 10 & & & \\
\hline & Kaçıncı Kat & 5 & & & \\
\hline & Daire Şekli & 10 & & & \\
\hline & Balkon Sayısı & 10 & & & \\
\hline & Bina Yaşı & 10 & & & \\
\hline \multirow[t]{2}{*}{ Sosyal Kullanım Alanı } & Oyun parkı var & 10 & 20 & & \\
\hline & Spor Alanı var & 10 & & & \\
\hline \multirow[t]{5}{*}{ Yapı Çevresinin Özellikleri } & Otopark & 10 & 50 & & \\
\hline & Yangın Merdiveni & 10 & & & \\
\hline & Isitma Sistemi & 10 & & & \\
\hline & Ses Yalıtımı & 10 & & & \\
\hline & Asansör & 10 & & & \\
\hline \multirow[t]{3}{*}{ Güvenlik Hizmeti } & Güvenlik & 10 & 30 & & \\
\hline & Apartman Görevlisi & 10 & & & \\
\hline & Site & & & & \\
\hline Engelliye Uygunluğu & & & 10 & & \\
\hline Yüzme Havuzu & & & 0 & & \\
\hline $\mathrm{m}^{2}$ & & & 10 & & \\
\hline TOPLAM & & & 195 & & \\
\hline
\end{tabular}

EV 1 için altyapı, nüfus ve ulaşım ana kriterlerinden yapılan puanlama AHP ile hesaplanan lokal ağırlıklar ile çarpılarak EV 1 için yapısal puan bulunmuştur. Bütün örneklem seçilen evler için bu işlemler gerçekleștirilmiştir.

\subsection{Taşınmaz Değerine Etki Eden Konumsal Faktörlerin CBS ve AHP Yardımıyla Analizi}

Konum bir taşınmazın değeri için en önemli faktörlerden bir tanesidir. Taşınmazın ulaşım noktaları ve sosyo-kültürel donatı gibi tesislere uzaklığı oldukça önemlidir. Eğitim tesisleri, eğlence alanları, ibadethaneler ve toplu taşıma yerlerine olan uzaklıklar zaman ve uzunluk yönünden değerlendirilir ve taşınmaz değerine yansıtılır.

Çalışmada taşınmazların konumsal analizlerinin yapılabilmesi amacıyla ArcGIS 10.6 
yazılımı yardımıyla Buffer analizi ve haritaları üretilmiștir. Seçilen 30 dairenin konumsal özelikleri incelenirken; ulaşım tesisleri (durak-konut mesafesi), eğitim tesisleri, ibadet alanları, sağlık hizmetleri ve yeşil alanlara olan mesafe dikkate alınmıştır. Ayrıca üniversiteye yakınlık kent için önemli bir faktör olarak kabul edilmiştir.

Şekil 8'de görüldüğü gibi taşınmazın değerine etki eden konumsal faktörler taşınmazın mesafesine göre puanlandırılmıştır. Ardından AHP yöntemi ile uzman görüşlerine dayanılarak belirlenen konum ana kriteri ve alt kriterlerine yönelik lokal ağırlıklar ile her bir konum puanı çarpılmıştır. Her ev için ağırlıklı toplam konumsal puan elde edilmiştir. Burada her taşınmazın konumsal faktörlere (sağlık tesisi, eğitim tesisi, vb.) olan puanlarının toplamı taşınmazın konum puanı olarak belirlenmiștir (Tablo 7).

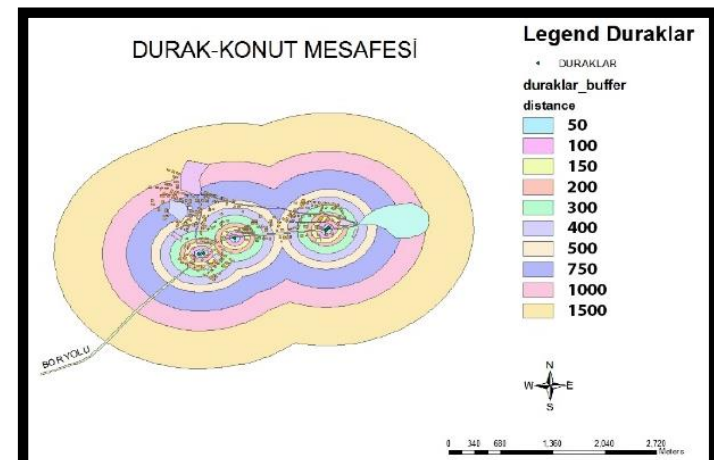

IBADET ALANLARI - KONUT MESAFESI
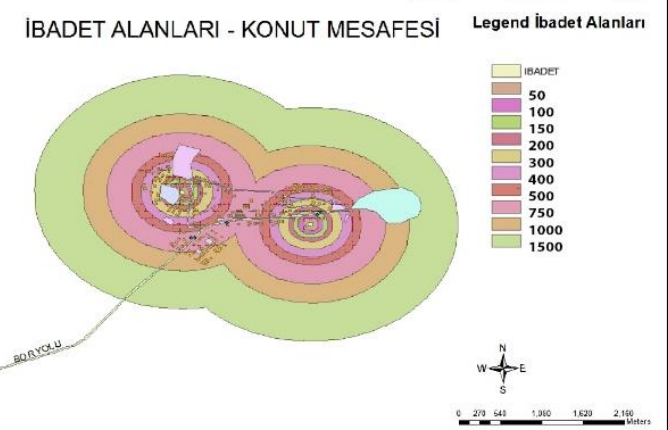

ÜNIVERSITE ALANI - KONUT MESAFESI
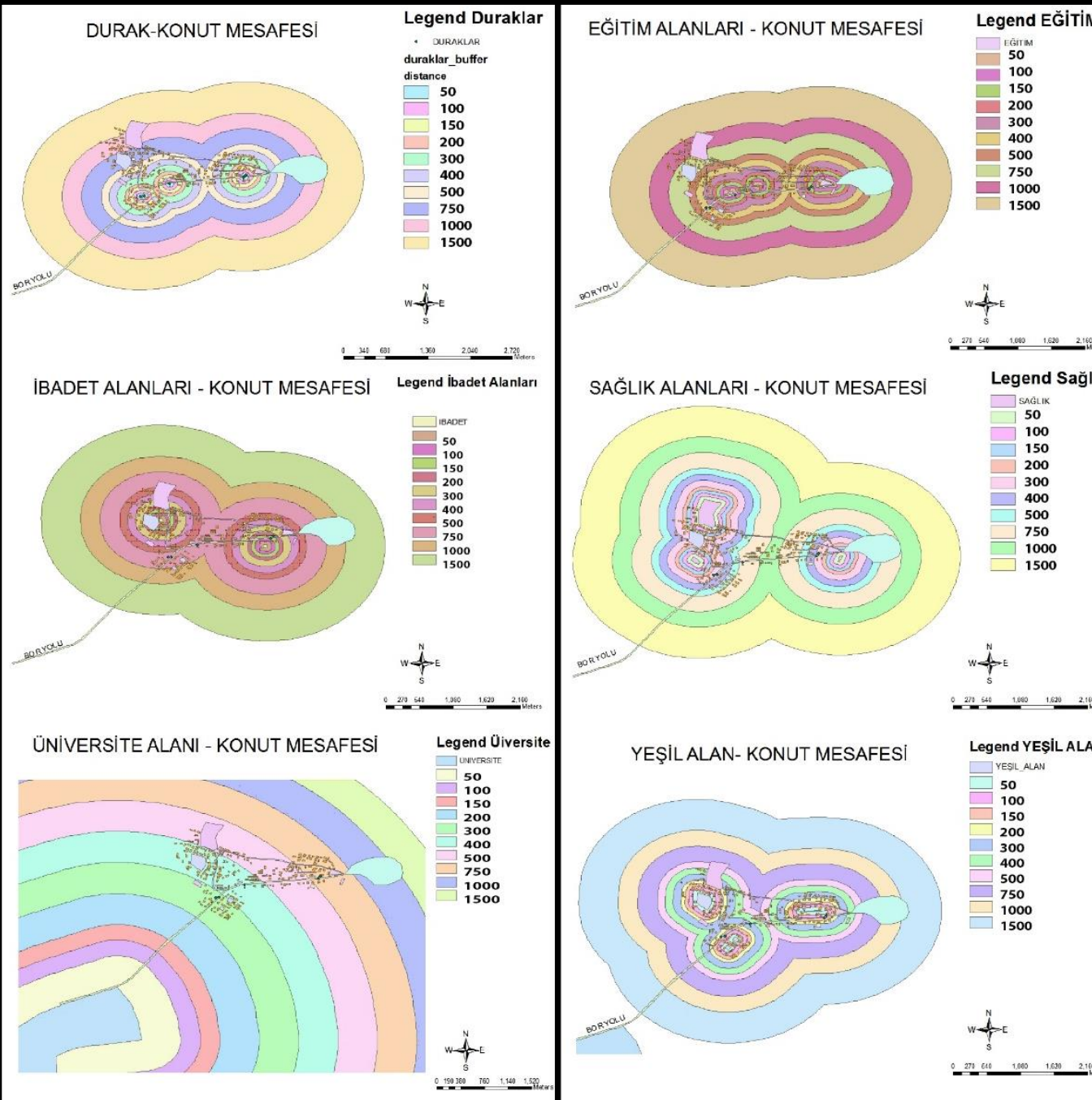

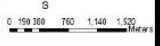

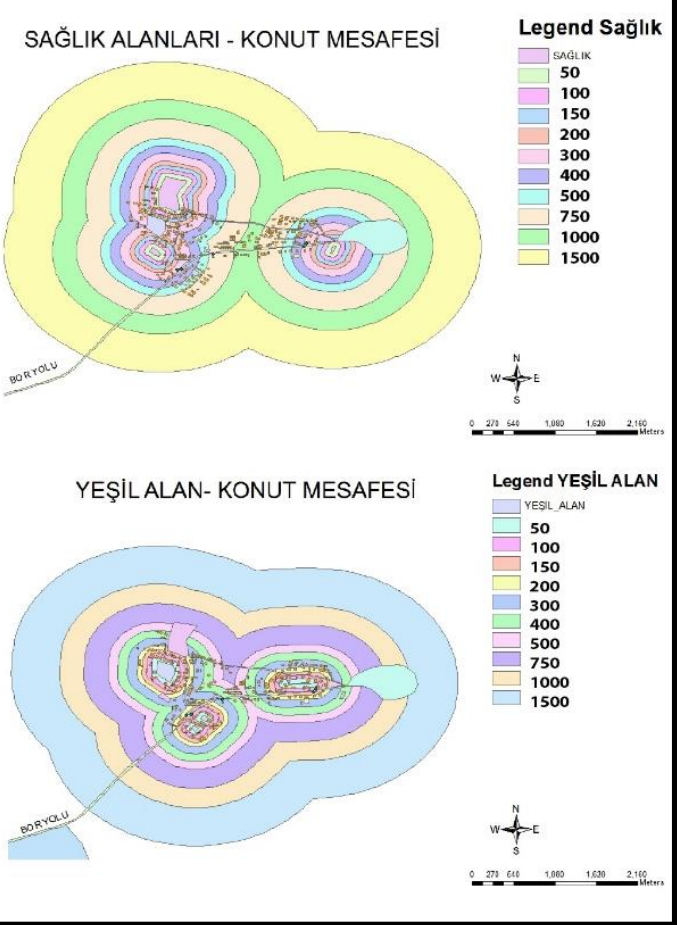

Şekil 8. a) Durak- Konut Mesafesi Buffer Analizi, b) Eğitim- Konut Mesafesi Buffer Analizi, c) İbadet Alanları- Konut Mesafesi Buffer Analizi, d) Sağlık Alanları- Konut Mesafesi Buffer Analizi e) Üniversite Alanı- Konut Mesafesi Buffer Analizi f) Yeșil Alan - Konut Mesafesi Buffer Analizi 
Tablo 7. Her Ev İçin CBS ve AHP Yardımıyla Olușturulan Konumsal Puan Tablosu

\begin{tabular}{|c|c|c|c|c|c|c|c|c|c|c|c|c|c|c|c|}
\hline & \begin{tabular}{|l|} 
KENT \\
MERKEZINE \\
UZAKLIK
\end{tabular} & \begin{tabular}{|l|} 
AĞIRLIKLI \\
PUAN
\end{tabular} & ЕĞітім U. & \begin{tabular}{|l} 
AĞIRLIKLI \\
PUAN
\end{tabular} & $\begin{array}{l}\text { SAĞLIK } \\
\text { KURUMUNA U. }\end{array}$ & \begin{tabular}{|l|} 
AĞIRLILI SAĞLIK \\
PUAN
\end{tabular} & \begin{tabular}{|l|} 
YEŞiL \\
ALANLARINA \\
UZAKLIǦI
\end{tabular} & $\begin{array}{l}\text { AĞIRLLKLI } \\
\text { PUAN }\end{array}$ & $\begin{array}{l}\text { IBADET } \\
\text { ALANLARINA } \\
\text { UZAKLIĞI }\end{array}$ & $\begin{array}{l}\text { AĞIRLIKLI } \\
\text { PUAN }\end{array}$ & \begin{tabular}{|l|} 
DURAK \\
UZAKLIĞI
\end{tabular} & $\begin{array}{l}\text { AĞIRLIKLI } \\
\text { PUAN }\end{array}$ & $\begin{array}{l}\text { ANAYOL } \\
\text { UZAKLIĞI }\end{array}$ & $\begin{array}{l}\text { AĞIRLIKLI } \\
\text { PUAN }\end{array}$ & TOPLAM PUAN \\
\hline EV1 & 8 & 6,253192 & 5 & 3,13613 & 3 & 1,773336 & 9 & 5,11164 & $4 \quad 6$ & 22,38591 & 5 & 4,722413025 & 10 & \begin{tabular}{|c|}
9,38770708 \\
\end{tabular} & 52,77032811 \\
\hline EV 2 & 9 & 7,034841 & 7 & 4,390582 & 5 & 2,95556 & 10 & 5,6796 & 5 & 22,38591 & 8 & 7,55586084 & 8 & 7,51016566 & 57,5125195 \\
\hline EV 3 & 9 & 7,034841 & 5 & \begin{tabular}{|l|}
3,13613 \\
\end{tabular} & 3 & 1,773336 & 9 & 5,11164 & 4 & 22,38591 & 6 & 5,66689563 & 7 & 6,57139496 & 51,68014759 \\
\hline EV 4 & 10 & $\begin{array}{l}7,81649 \\
\end{array}$ & 8 & 5,017808 & 5 & 2,95556 & 7 & 3,97572 & 2 & 18,654925 & 6 & 5,66689563 & 6 & 5,63262425 & 49,72002288 \\
\hline EV 5 & 10 & 7,81649 & 8 & 5,017808 & 6 & 3,546672 & 6 & 3,40776 & 5 & 18,654925 & 6 & \begin{tabular}{|l|}
5,66689563 \\
\end{tabular} & 7 & 6 & 50,68194559 \\
\hline EV 6 & 9 & 7,034841 & 6 & 3,763356 & 5 & 2,95556 & 9 & 5,11164 & if & \begin{tabular}{|l|}
29,84788 \\
\end{tabular} & 9 & 8,500343445 & 10 & \begin{tabular}{|l|}
9,38770708 \\
\end{tabular} & 66,60132753 \\
\hline EV 7 & 8 & 6,253192 & 4 & 2,508904 & 3 & 1,773336 & 7 & 3,97572 & 2 & 14,92394 & 5 & 4,722413025 & 5 & \begin{tabular}{|l|}
4,69385354 \\
\end{tabular} & 38,85135857 \\
\hline EV 8 & 5 & 3,908245 & 4 & 2,508904 & 5 & 2,95556 & 4 & 2,27184 & if & 14,92394 & 4 & 3,77793042 & 2 & \begin{tabular}{|l|}
1,87754142 \\
\end{tabular} & 32,22396084 \\
\hline EV 9 & 6 & 4,689894 & 9 & 5,645034 & 3 & 1,773336 & 4 & 2,27184 & if & 11,192955 & 6 & 5,66689563 & 8 & \begin{tabular}{|l|}
7,51016566 \\
\end{tabular} & 38,75012029 \\
\hline EV 10 & 5 & 3,908245 & 10 & 6,27226 & 4 & 2,364448 & 6 & 3,40776 & 4 & 14,92394 & 8 & 7,55586084 & 9 & \begin{tabular}{|l|}
8,44893637 \\
\end{tabular} & 46,88145021 \\
\hline EV 11 & 5 & 3,908245 & 7 & 4,390582 & 4 & 2,364448 & 5 & 2,8398 & 5 & 18,654925 & 6 & 5,66689563 & 6 & 5,63262425 & 43,45751988 \\
\hline EV 12 & 7 & 5,471543 & 8 & \begin{tabular}{|l|l|}
5,017808 \\
\end{tabular} & 2 & 1,182224 & 6 & 3,40776 & 5 & 18,654925 & 4 & 3,77793042 & 10 & \begin{tabular}{|l|}
9,38770708 \\
\end{tabular} & 46,8998975 \\
\hline EV 13 & 10 & 7,81649 & 8 & 5,017808 & & 4,137784 & 7 & 3,97572 & 9 & 33,578865 & 10 & 9,44482605 & 10 & \begin{tabular}{|c|}
9,38770708 \\
\end{tabular} & 73,35920013 \\
\hline EV 14 & 6 & 4,689894 & 8 & 5,017808 & 2 & 1,182224 & 5 & \begin{tabular}{|c|}
2,8398 \\
\end{tabular} & 3 & 11,192955 & 6 & 5,66689563 & 10 & \begin{tabular}{|l|l|}
9,38770708 \\
\end{tabular} & 39,97728371 \\
\hline EV 15 & 5 & 3,908245 & 9 & 5,645034 & $\frac{4}{3}$ & 1,773336 & & 3,40776 & $\frac{3}{3}$ & $\mid$ & 10 & \begin{tabular}{l|}
9,44482605 \\
9
\end{tabular} & 10 & \begin{tabular}{|l|l|}
9,38770708 \\
\end{tabular} & 44,75986313 \\
\hline EV 16 & 7 & 5,471543 & 8 & 5,017808 & $\frac{2}{2}$ & 1,182224 & 6 & 3,40776 & 5 & $\mid 14,92394$ & 4 & 3,77793042 & 10 & \begin{tabular}{|l|l|}
9,38770708 \\
\end{tabular} & 43,1689125 \\
\hline EV 17 & 8 & 6,253192 & & 5,645034 & & 1,182224 & 6 & 3,40776 & 5 & 11,192955 & 4 & 3,77793042 & & \begin{tabular}{|l|}
6,57139496 \\
\end{tabular} & 38,03049038 \\
\hline EV 18 & 8 & 6,253192 & 5 & 3,13613 & 3 & 1,773336 & 10 & 5,6796 & 5 & 26,116895 & 6 & 5,66689563 & 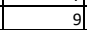 & \begin{tabular}{|l|}
8,44893637 \\
\end{tabular} & 57,074985 \\
\hline EV 19 & 4 & 3,126596 & 4 & 2,508904 & 7 & 4,137784 & 5 & 2,8398 & 3 & 22,38591 & 4 & 3,77793042 & 2 & \begin{tabular}{|l|}
1,87754142 \\
\end{tabular} & 40,65446584 \\
\hline EV 20 & 3 & 2,344947 & 3 & 1,881678 & 9 & 5,320008 & 7 & 3,97572 & 2 & 29,84788 & 3 & 2,833447815 & 1 & \begin{tabular}{|l|}
0,93877071 \\
\end{tabular} & 47,14245152 \\
\hline EV 21 & 0 & 0 & 2 & 1,254452 & 7 & 4,137784 & 7 & 3,97572 & 2 & 18,654925 & 3 & 2,833447815 & 0 & 0 & 30,85632882 \\
\hline EV 22 & 0 & 0 & 2 & 1,254452 & 10 & 5,91112 & 6 & 3,40776 & 5 & \begin{tabular}{|l|l|}
18,654925 \\
\end{tabular} & 1 & 0,944482605 & 0 & 0 & 30,17273961 \\
\hline EV 23 & 3 & 2,344947 & 6 & 3,763356 & 6 & 3,546672 & 7 & 3,97572 & 2 & 22,38591 & 5 & 4,722413025 & 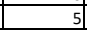 & \begin{tabular}{|l|}
4,69385354 \\
\end{tabular} & 45,43287157 \\
\hline EV 24 & 4 & 3,126596 & 7 & 4,390582 & 5 & 2,95556 & 5 & 2,8398 & 8 & 18,654925 & 6 & 5,66689563 & & 6,57139496 & 44,20575359 \\
\hline EV 25 & 1 & 0,781649 & 3 & 1,881678 & 7 & 4,137784 & 9 & 5,11164 & 4 & 22,38591 & 3 & 2,833447815 & 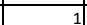 & \begin{tabular}{|l|}
0,93877071 \\
\end{tabular} & 38,07087952 \\
\hline EV 26 & 2 & 1,563298 & 5 & 3,13613 & 9 & 5,320008 & 6 & 3,40776 & 5 & 14,92394 & 8 & 7,55586084 & & 6,57139496 & 42,4783918 \\
\hline EV 27 & 4 & 3,126596 & 7 & 4,390582 & 4 & 2,364448 & 9 & 5,11164 & it & 11,192955 & 7 & 6,611378235 & & 8,44893637 & 41,24653561 \\
\hline $\operatorname{EV} 28$ & 2 & 1,563298 & 4 & 2,508904 & 5 & 2,95556 & 9 & 5,11164 & 4 & 11,192955 & 7 & 6,611378235 & & \begin{tabular}{|l|}
8,44893637 \\
\end{tabular} & 38,39267161 \\
\hline $\operatorname{EV} 29$ & 4 & 3,126596 & 5 & 3,13613 & 3 & 1,773336 & 9 & 5,11164 & 4 & 7,46197 & 6 & \begin{tabular}{|l|}
5,66689563 \\
\end{tabular} & 5 & \begin{tabular}{|l|}
4,69385354 \\
\end{tabular} & 30,97042117 \\
\hline EV 30 & 8 & 6,253192 & 5 & 3,13613 & 3 & 1,773336 & 7 & 3,97572 & 8 & 29,84788 & 6 & 5,66689563 & 10 & 9,38770708 & 60,04086071 \\
\hline
\end{tabular}

\subsection{AHP ve CBS ile Belirlenen Taşınmaz Değerlerinin Piyasa Değerleri ile Karşılaştırılması}

Her ev için AHP ve CBS yardımıyla belirlenen yapisal ve konumsal puanlar toplanarak toplam puan elde edilir. Toplam puan ve piyasa değeri ayrı ayrı normalize edilerek birbiriyle karşılaştırılması yapılmıștır (Tablo 8).

Çalışmada örneklem seçilen taşınmazların AHP ve CBS yardımıyla belirlenen taşınmaz değerlerinin piyasa değerleri ile uyumlu olduğu görülmüştür. Bazı taşınmazlarda (ev 4, ev 8, ve ev 17) piyasa değerlerinde diğer taşınmazlara göre ani sıçramalar olduğu görülmüştür. Günümüz şartlarında inşaat sektörüne yansıyan ekonomik sebepler ve örneklem alınan evlerdeki standartların (oda sayısı, balkon sayısı, tuvalet banyo sayısı, metrekaresi, kullanılan malzeme kalitesi vs.) değişim göstermesinden kaynaklı olarak taşınmazların değerinde artışlar meydana gelmiştir.

Genel olarak Şekil 9 incelendiğinde AHP ve CBS ile bulunan taşınmaz değerleme sonuçlarının rant artışını önlemeye yönelik objektif ölçülerle taşınmaz değer değişiminin belirlenmesinde bir yöntem olabileceğini göstermiştir. Sonuçların olumsuz gidebilecek piyasa koșularını önleyerek dengeli bir değerleme göstereceği belirlenmiştir.

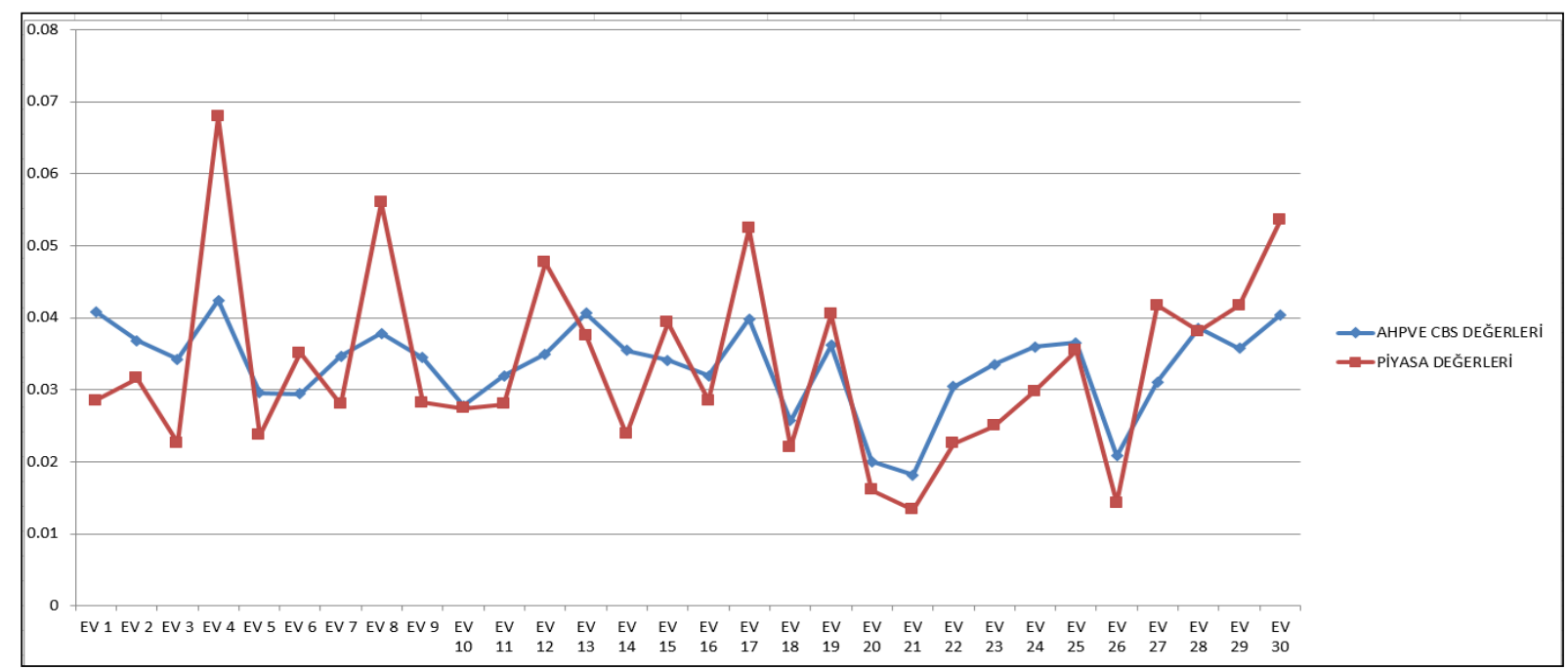

Şekil 9. Konumsal Değer ve Piyasa Değeri İlişkisi 
Tablo 8. Toplam Puan (Konumsal Puan) Tablosu

\begin{tabular}{|c|c|c|c|c|c|c|}
\hline & YAPISAL PUAN & KONUMSAL PUAN & TOPLAM PUAN & NORMALIZE PUAN & PIYASA DEĞERI & NORMALIZASYON \\
\hline EV 1 & 304,2542 & 52,7703281 & 357,0245281 & 0,040839757 & 239 & 0,028459157 \\
\hline EV 2 & 264,46 & 57,5125195 & 321,9725195 & 0,036830185 & 265 & 0,031555132 \\
\hline EV 3 & 247,4054 & 51,6801476 & 299,0855476 & 0,034212163 & 190 & 0,022624434 \\
\hline EV 4 & 321,3088 & 49,72002288 & 371,0288229 & 0,042441698 & 570 & 0,067873303 \\
\hline EV 5 & 207,6113 & 50,68194559 & 258,2932456 & 0,029545963 & 199 & 0,023696118 \\
\hline EV 6 & 190,5566 & 66,60132753 & 257,1579275 & 0,029416095 & 295 & 0,035127411 \\
\hline EV 7 & 264,46 & 38,85135857 & 303,3113586 & 0,03469555 & 235 & 0,027982853 \\
\hline EV 8 & 298,5693 & 32,22396084 & 330,7932608 & 0,037839183 & 470 & 0,055965706 \\
\hline EV 9 & 262,1086 & 38,75012029 & 300,8587203 & 0,034414994 & 237 & 0,028221005 \\
\hline EV 10 & 196,2415 & 46,88145021 & 243,1229502 & 0,027810645 & 230 & 0,027387473 \\
\hline EV 11 & 236,0357 & 43,45751988 & 279,4932199 & 0,031971011 & 235 & 0,027982853 \\
\hline EV 12 & 258,7752 & 46,8998975 & 305,6750975 & 0,034965936 & 400 & 0,047630388 \\
\hline EV 13 & 281,5147 & 73,35920013 & 354,8739001 & 0,040593749 & 315 & 0,037508931 \\
\hline EV 14 & 270,1449 & 39,97728371 & 310,1221837 & 0,035474635 & 200 & 0,023815194 \\
\hline EV 15 & 253,0903 & 44,75986313 & 297,8501631 & 0,034070848 & 330 & 0,03929507 \\
\hline EV 16 & 236,0357 & 43,1689125 & 279,2046125 & 0,031937998 & 239 & 0,028459157 \\
\hline EV 17 & 309,9391 & 38,03049038 & 347,9695904 & 0,03980397 & 440 & 0,052393427 \\
\hline EV 18 & 167,8171 & 57,074985 & 224,892085 & 0,02572523 & 185 & 0,022029055 \\
\hline EV 19 & 275,8298 & 40,65446584 & 316,4842658 & 0,036202388 & 340 & 0,04048583 \\
\hline EV 20 & 128,023 & 47,14245152 & 175,1654515 & 0,020037039 & 135 & 0,016075256 \\
\hline EV 21 & 128,023 & 30,85632882 & 158,8793288 & 0,018174083 & 112 & 0,013336509 \\
\hline EV 22 & 236,0357 & 30,17273961 & 266,2084396 & 0,030451376 & 189 & 0,022505358 \\
\hline EV 23 & 247,4054 & 45,43287157 & 292,8382716 & 0,033497542 & 210 & 0,025005954 \\
\hline EV 24 & 270,1449 & 44,20575359 & 314,3506536 & 0,035958326 & 250 & 0,029768993 \\
\hline EV 25 & 281,5147 & 38,07087952 & 319,5855795 & 0,036557145 & 298 & 0,035484639 \\
\hline EV 26 & 139,3927 & 42,4783918 & 181,8710918 & 0,020804092 & 120 & 0,014289116 \\
\hline EV 27 & 230,3508 & 41,24653561 & 271,5973356 & 0,031067807 & 350 & 0,04167659 \\
\hline EV 28 & 298,5693 & 38,39267161 & 336,9619716 & 0,038544817 & 320 & 0,038104311 \\
\hline EV 29 & 281,5147 & 30,97042117 & 312,4851212 & 0,035744929 & 350 & 0,04167659 \\
\hline EV 30 & 292,8844 & 60,04086071 & 352,9252607 & 0,040370845 & 450 & 0,053584187 \\
\hline TOPLAM PUAN & & & 8742,082505 & & 8398 & \\
\hline
\end{tabular}

\section{SONUÇLAR ve TARTIŞMA}

Taşınmaz değerleme kentsel ve kırsal alanların gelişimini ve imar ve şehircilik sürecini etkileyen bir süreçtir. $\mathrm{Bu}$ sürecin objektif ölçütlerle tamamlanabilmesi için taşınmaz değerine etki eden kriterlerin belirlenmesi oldukça önemlidir. $\mathrm{Bu}$ çalışmada bu kriterlerin belirlenmesi aşamasında mühendis ve teknik nitelikteki uzmanlardan anket uygulaması ile görüş alınması aşamasında literatürle uyumluluk göstermektedir. Ayrıca çalışma birbiriyle yüksek korelasyonu olan kriterlerin elenmesi açısından bir yöntem olarak çok kriterli karar analizi yöntemlerinden biri olan AHP kullanılmasıyla literatüre uyumluluk göstermektedir.

$\mathrm{Bu}$ çalışmada Niğde kentinin taşınmaz değerleme süreci objektif bir açıdan incelenmiştir. Bunun için belirlenen bir gelişme bölgesine ait taşınmaz değerine etki eden kriterler AHP yöntemi ile ağırlıklandırılmıştır. Elde edilen kriterlerden istatistiksel olarak anlaml kabul edilen kriterlerin ağırlıklarına yönelik örneklem alınan yapıların yapı özellikleri puanlaması yapılmıştır. Bununla birlikte örneklem alınan yapıların konum özellikleri CBS yardımıyla değerlendirilmiş ve puanlandırılmıştır.
Sonuçta AHP ve CBS yardımıyla belirlenen taşınmaz değerlerine yönelik yapısal ve konumsal puanların toplamı normalize edilerek piyasa değerleri ile karşılaştırılmış ve incelenmiştir. AHP ve CBS yardımıyla elde edilen değerlerin piyasa değerleriyle uyumlu olduğu tespit edilmiştir.

$\mathrm{Bu}$ çalışma taşınmaz değerleme sürecinde; olumsuz piyasa koşullarının önlenmesi, objektif değerlemenin gerçekleştirilebilmesi ve CBS ve AHP yardımıyla piyasa değerlerini dengeleyen değerlemenin gerçekleştirilebilmesi yönüyle literatüre katkı sağlamıştır. Ayrıca bu çalışma gelecek çalışmalar için taşınmaz değerleme sürecinin objektif, adaletli rant ve spekülatif etkileri önlenmiş nitelikte yapılabilmesinde mahalle bazlı ya da bölgesel ölçekte çalışmalara rehber nitelik taşıyacaktır.

\section{KAYNAKÇA}

Açlar, A. ve Çagdas, V. (2002). Taşınmaz (Gayrimenkul) değerlemesi. Birinci Baskı, TMMOB Harita ve Kadastro Mühendisleri Odası, Ankara. 
Akalın, M., Turhan, G. ve Şahin, A. (2013). The application of AHP approach for evaluating location selection elements for retail store: A case of clothing store. International Journal of Research in Business and Social Science, 2, 4, 120.

Amca, F. (2016). Gayrimenkul değerlemesi ve Denizli Merkez'de bir uygulama. Yüksek Lisans Tezi, Pamukkale Üniversitesi Sosyal Bilimler Enstitüsü, 13-38.

Bahar, M.E. (2007). Taşınmaz değerlemesinde CBS'nin kullanım olanakları. Yüksek Lisans Tezi, Istanbul Teknik Üniversitesi Fen Bilimleri Enstitüsü, İstanbul.

Bunruamkaew, K. (2012). How to do AHP analysis in Excel. GIS Seminar, division of spatial information science graduate school of life and environmental sciences, university of Tsukuba.

Chen, C. (2006). Applying the analytical hierarchy process (AHP) approach to convention site selection. Journal of Travel Research, 45, 167174.

Demirel, B., Yelek, A., Alağaş, M. ve Eren, T. (2018). Taşınmaz değerleme kriterlerinin belirlenmesi ve kriterlerin önem derecelerinin çok ölçütlü karar verme yöntemi ile hesaplanması. Kırıkkale Üniversitesi Sosyal Bilimler Dergisi, 10-18.

Derinpınar, M. ve Aydınoğlu, A. (2015). Bulanık Mantık ile Coğrafi Bilgi Teknolojilerini kullanarak taşınmaz değerlemesi. 15. Türkiye Harita Bilimsel ve Teknik Kurultayı.

Döner, S. (2010). CBS destekli taşınmaz mal değer haritalarının olușturulması. Yüksek Lisans Tezi, İstanbul Teknik Üniversitesi Fen Bilimleri Enstitüsü.

Döner, S. ve Alkan, R. (2011). CBS destekli taşınmaz mal değer haritalarının olușturulması. 13. Türkiye Harita Bilimsel ve Teknik Kurultayı.

Erbil, H. (2014). Taşınmaz mal değerleme amaçlı Coğrafi Bilgi Sistemi tasarımı. Uzaktan Algılama-CBS Sempozyumu (Uzal-CBS 2014).

Erdem, N. (2017a). Toplu (küme) değerleme uygulama örnekleri ve ülkemiz için öneriler. 16. Türkiye Harita Bilimsel ve Teknik Kurultayı.

Erdem, N. (2017b). Türkiye için bir taşınmaz değerleme sistemi yaklaşımı. Geomatik, 2(1),1836.

Erdem, N. (2019). Türkiye taşınmaz değerleme sisteminin etkinliğinin araștırılması,
Geomatik,4(1),1-13.

DOI:10.29128/geomatik.418870.

Ersöz, F., ve Kabak M. (2010). Savunma sanayi uygulamalarında çok kriterli karar verme yöntemlerinin literatür araştırması. Savunma Bilimleri Dergisi, 9(1),97-125.

Ertaş, M. ve Bayındır, B. (2017). Valuation of Residences through Utilizing Ratio of Integrated Capitalization, International Journal of Engineering and Geosciences (IJEG), 2 (3), 9199.DOI: 10.26833/ijeg.321278.

Ertaș, M. Education for Real Estate Valuation in Turkey, International Journal of Engineering and Geosciences (IJEG), 4 (1),8-15. DOI: 10.26833/ijeg.416336.

George, D. and Mallery, P. (2010). SPSS for Windows Step by Step: A Simple Guide and Reference 17.0 Update. 10th Edition, Pearson, Boston.

Güngör, E. (1999). Taşınmaz mal değerlemesi ve Türkiye'de sermaye piyasalarında taşınmaz mal ekspertiz șirketlerine yönelik düzenlemeler yapılmasına ilișkin öneriler. TC Bașbakanlık Sermaye Piyasası Kurulu Kurumsal Yatırımcilar Dairesi, Ankara.

Hamurcu, M. ve Eren, T. (2017). Raylı sistem projeleri kararında AHS-HP Ve AAS-HP kombinasyonu. Gazi Mühendislik Bilimleri Dergisi, 3(3), 1-13.

Özer, M. (2010). Taşınmaz değerlemesinde kullanılan finansal ve sayısal yöntemler: Topsıs ve yeni çoklu kriter modelleriyle bir uygulama. Yüksek Lisans Tezi, Dokuz Eylül Üniversitesi Sosyal Bilimler Enstitüsü, 113-115.

Saaty, T.L. (1980), The analytic hierarchy process: Planning, priority setting. Resources Allocation. Mcgraw-Hill, New York.

Tarin, E. (2013). Yerel yönetimlerde emlak vergisi matrahının tespiti, karşılaşılan sorunlar ve çözüm önerileri. Yüksek Lisans Tezi, Ístanbul Aydın Üniversitesi Sosyal Bilimler Enstitüsü, İstanbul.

Timur, S., (2019). Coğrafi Bilgi Sistemleri destekli taşınmaz değerleme haritalarının oluşturulması: İstanbul İli Şişli İlçesi örneği. Yüksek Lisans Tezi, İstanbul Teknik Üniversitesi Fen Bilimleri Enstitüsü, İstanbul.

Torun, M., Yanalak, M. ve Şeker, D. (2009). Taşınmaz değer haritalarının Coğrafi Bilgi Sistemleri ile üretilmesi. 12. Türkiye Harita Bilimsel ve Teknik Kurultayı. 
Uludağ, A.S. ve Doğan, H. (2016). Çok kriterli karar verme yöntemlerinin karşılaştırılmasına odaklı bir hizmet kalitesi uygulaması. Cankırı Karatekin Üniversitesi İktisadi ve İdari Bilimler Fakültesi Dergisi, 6 (2), 17-47.

Ünel, F. ve Yalpir, S. (2014). Determination of the locational, physical and legal status of parcels using the AHP Method and GIS in real estate valuation. Geomatics Engineering Department, Selcuk University, 1-10.

Ünel, F. ve Yalpir, Ş. (2019). Türkiye'de Taşınmazların Değerini Etkileyen Kriterlere Yaklaşım. Geomatik, 4 (2), 112-133. DOI:10.29128/geomatik.499681.

Ünel, F., Yalpir, Ş. And Gülnar, B., Preference Changes Depending on Age Groups Of Criteria Affecting the Real Estate Value, International Journal of Engineering and Geosciences (IJEG), 2 (2), 41-51. DOI: 10.26833/ijeg.297271.

Yağmahan, G. (2019). Puanlama yöntemiyle taşınmaz değerlerinin belirlenmesi ve yaşam kalitesiyle ilişkisinin araştırılması. Yüksek Lisans Tezi, Ylldız Teknik Üniversitesi Fen Bilimleri Enstitüsü, İstanbul.

Yalpır, Ş. ve Ekiz, M. (2017). Eşdeğerlilik esaslı arazi ve arsa düzenlemesinde analitik hiyerarși prosesinin kullanımı. Ömer Halisdemir Üniversitesi Mühendislik Bilimleri Dergisi, 60-65.

Yılmaz, A. ve Demir, H. (2011). Çok ölçütlü karar destek sistemleri ile taşınmaz değerleme ve oran çalışması. 13. Harita Bilimsel ve Teknik Kurultayl, 3-6. 